\author{
Дишкантюк О.В. \\ кандидат технічних наук, доцент \\ кафедра готельно-ресторанного бізнесу \\ Одеська національна академія харчових технологій \\ вул. Канатна, 112, м. Одеса, Україна, 65039 \\ E-mail: dyshkantyuk@ukr.net
}

\title{
ЕКОНОМІКА ВРАЖЕНЬ - СУЧАСНИЙ ЕТАП РОЗВИТКУ СУСПІЛЬНОГО ВИРОБНИЦТВА
}

В статті розглянуто передумови розвитку економіки вражень як сучасного етапу суспільного виробництва; визначено сутність кінцевих та проміжних послуг сфери гостинності та кінцевого її продукту; досліджено логістичні ланцюги сфери гостинності, що формують продукт гостинності та наведено приклади їх існування.

Ключові слова: економіка вражень, гостинність, кінцеві та проміжні послуги, продукт гостинності, логістичний ланцюг, зелена логістика.

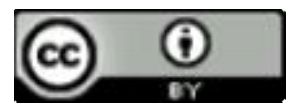

This work is licensed under a Creative Commons Attribution 4.0 International License http://creativecommons.org/licenses/by/4.0/
Постановка проблеми та їі зв'язок з важливими науковими та практичними завданнями. В сучасному світі формуються тенденції підвищення інвестиційної привабливості національної економіки, толерантності суспільства та акцентується увага на розвитку соціальної сфери. Основним трендом економічного розвитку є перехід до нового мислення та сприйняття сучасного етапу суспільних відносин, в якому пріоритети для споживачів полягають не стільки у товарах та послугах, скільки у враженнях, які вони від цього отримують. Перехід до нової економіки, коли споживач хоче та може купити не сировину, товари, послуги, бо в принципі вони рівнозначні, а враження, тобто час, проведений в певній сфері матеріального або нематеріального виробництва може бути визначено як пріоритетний напрям стратегії соціально-економічного розвитку секторів національної економіки. Це стосується, в першу чергу, нематеріальної сфери виробництва - розваг, ресторанів, готелів, банків про що свідчить досвід розвинених країн світу та спрямованість їх пріоритетів на глобалізаційний наднаціональний розвиток, відповідно й появу нових наукових напрямів та понять таких як: сервісна індустрія, індустрія гостинності, креативна економіка тощо. На фоні створення нових економічних моделей, нових типів соціальних відносин та нових підходів до збереження та розвитку культурних традицій актуалізуються питання визначення основних засад розвитку економіки гостинності та вражень.

Аналіз останніх публікацій 3 проблеми. В сучасних умовах політичний розвиток країн світу та дослідження вчених направлені на пріоритети соціальної сфери. В програмних документи уряду України також визнається, що пріоритетним напрямом державної політики є підвищення якості життя [1-5]. Підвищення якості життя нерозривно зв'язане з гостин- ністю, найвищим виразом якої є враження, які отримує людина в процесі життєдіяльності. Науковці також приділяють багато уваги розвитку гостинності, та вивчають їі в основному у сфері туризму. Слканова Д.І., Осипов Д.А., Романов В.В., Сорокіна О.В. пропонують розглядати гостинність як сукупність засобів і методів, за допомогою яких забезпечується і досягається необхідний рівень комфорту та стверджують що це - складова частина будь-якого сервісу, і без нього не обходиться жодне готельне підприємство. 3 погляду Р.А. Браймера, індустрія гостинності $\epsilon$ об'єднуючим поняттям для різноманітних і численних форм підприємництва, які спеціалізуються на ринку послуг, пов'язаному 3 прийомом і обслуговуванням гостей [6]. Основні напрямки індустрії гостинності: громадське харчування, розміщення, перевезення і відпочинок. Деякі вчені стверджують, що гостинність забезпечується комплексним туристичним продуктом [7, 8, с. 30]. Н. Вебстер дає визначення індустрії гостинності як сфери підприємництва, що складається 3 таких видів обслуговування, які спираються на принципи гостинності, що характеризуються щедрістю і дружелюбністю по відношенню до гостей [9]. В дослідженнях вчених відсутній погляд на гостинність як логістичний ланцюг проміжних та кінцевих послуг, що формує економіку вражень.

Формулювання цілей дослідження. Мета статті дослідити передумови формування економіки вражень та індустрії гостинності як нового тренду суспільних та економічних відносин.

Основні завдання статті: визначити сутність кінцевих та проміжних послуг сфери гостинності; надати поняття кінцевого продукту гостинності; дослідити логістичні ланцюги сфери гостинності, що формують продукт гостинності. 
Виклад основних результатів і їх обгрунтування. На протязі всього розвитку продуктивних сил, що визначають систему базових та надбудовних економічних відносин змінювалися пріоритети виробництва. Від простого забезпечення предметами першої необхідності та сировиною до отримання вражень від споживання товарів та послуг.

Насичення суспільства різними товарами в середньому однієї якості та ціни (європейські стандарти якості продуктів харчування обов'язкові для всіх країн союзу) не тільки однієї держави, але й рівних по економічному розвитку країн веде суспільство до нових пріоритетів - це одержання вражень від отриманих послуг у різних сферах діяльності людства, в т.ч. послуг гостинності. Надання послуг в різних галузях економіки та суспільного відтворення розвивається швидкими темпами. Різноманітний спектр послуг охоплює всі сфери життя людини. Послуги підрозділяються на матеріальні та нематеріальні, побутові, житлово-комунальні, охорони здоров'я, освіти, культури, торгівлі, транспорту та зв'язку, туризму, розміщення, розваг, тощо. Багатоваріантність самих послуг та суб'єктів їх надання призводить до того, що трансакції і трансакційні витрати пошуку та здійснення необхідного варіанту послуг 3 одного боку зменшуються, а 3 другого - зростають.

Основними факторами зниження трансакцій та трансакційних витрат пошуку є:

- інформування через Internet та інші комунікаційні засоби продавців та споживачів про товар, ціну та якість; формації;

- зниження витрат часу та коштів на пошук ін-

- одержання корисної інформації про товар та обслуговування від різних споживачів;

- зниження витрат часу на оплату різних послуг та товарів.

Основними факторами підвищення трансакцій та трансакційних витрат пошуку є:

- складність здійснення вибору необхідного товару або послуги в розмаїтті запропонованих до продажу;

- неповнота інформації про товар або послугу призводить до придбання їх по більш високим цінам;

- недостовірність інформації про товар або послугу викликає додаткові трансакційні витрати;

- складність здійснення оцінки співвідношення якості, ціни та інших споживчих характеристик товару або послуги. При виборі послуги поки споживач не реалізує їі він не зрозуміє це співвідношення;

- суб'єктивність надання оцінок різними користувачами та споживачами товарів та послуг відносно ціни та якості.

Зараз немає необхідності затрачувати багато коштів та часу на одержання основних повсякденних послуг. Автоматизація праці, програмне забезпечення, що використовується при їх наданні, сприяє зменшенню кількості людей зайнятих в цій сфері, зниженню ціни та росту обсягів і якості послуг. На сучасному етапі розвитку продуктивних сил послуги звичайного обслуговування автоматизовано і вони сприймаються як стандартний процес, а людей більше цікавлять послуги, від яких вони отримують задоволення та враження. У випадку, коли послуги звичайного обслуговування не відповідають стандарту (по якості та кількості), то враження від них та від гостинності буде низьким. На нашу думку, враження складаються зі звичайного комплексу послуг (першого рівня) та зі специфічного обслуговування (другого рівня). Гостинність - це враження, які одержують люди від послуг першого та другого рівнів, які поділяються на проміжні та кінцеві, які формують продукт гостинності. До проміжного рівня на нашу думку слід віднести одиничні послуги, які не потребують комплексу взаємопов' язаних послуг, що перебувають у логістичному ланцюгу. Одним з критеріїв розподілу послуг за рівнями - це яскравість загального враження від одержання послуги.

Критеріями послуг, які необхідно відносити до першого або проміжного рівня мають виступати такі:

- загальні послуги - визначаються інфраструктурною забезпеченістю території (торгові мережі, транспорт, засоби комунікації, зв'язку тощо);

- загальні послуги - визначаються розвитком секторів економіки (промисловість, сільське господарство, культура, освіта, тощо);

- сприйняття позитивно загальних послуг гостинності при їх присутності (наприклад, наявність світла, води тощо), але без яскравого враження і це не $є$ основним фактором, що визначає гостинність;

- сприймання негативно гостинності при їх відсутності;

- еластичність попиту на ці послуги не змінюється в залежності від ціни та доходу;

- послуги, гранична корисність яких зменшується швидкими темпами;

До комплексу послуг першого або проміжного рівня відносяться такі:

- послуги виплати заробітної плати, пенсій, тощо;

- послуги оплати житлово-комунального господарства, кабельного телебачення, інтернету, телефоніі;

- послуги придбання квитків;

- послуги придбання товарів;

- послуги страхування;

- адміністративні послуги тощо.

Як видно з перерахованого переліку послуг, їх можна умовно віднести до першого рівня, тому що вони мають дискретний характер, не пов'язані між собою логістичним ланцюгом і в сукупності не справляють враження про продукт гостинності. Треба зауважити, що тільки в границях вироблення продукту гостинності ці послуги можуть бути пов'язаними між собою та справляти позитивне або негативне враження про продукт гостинності.

Критеріями віднесення послуг до другого або кінщевого рівня мають виступати такі послуги, які справляють яскраві враження і визначають кінцевий продукт гостинність: 
- сукупність проміжних послуг в межах інфраструктурного сектору, або між секторами, що формують кінцевий продукт гостинності та мають визначений ваговий коефіцієнт;

- сприйняття позитивно продукту гостинності при певному комплексі послуг, з яскравими враженнями і це $є$ основним фактором, що визначає гостинність;

- сприйняття негативно гостинності при певному комплексі послуг;

- еластичність попиту на кінцеві послуги змінюється в залежності від ціни та доходу;

- послуги, гранична корисність яких зменшується низькими темпами.

До комплексу послуг другого рівня необхідно віднести такі:

- послуги надання роботи та житла (приїжджим для одержання тимчасової або постійної роботи, освіти, лікування); відпочинку);

- послуги рекреації (лікування, оздоровлення,

- послуги туризму;

- послуги розміщення (готелі);

- послуги дозвілля;

- послуги відпочинку;

- послуги освіти;

- послуги охорони здоров’я;

- послуги культури.

Послуги другого або кінцевого рівня справляють на людей яскраві враження від гостинності, тому що за цими послугами люди їдуть на тимчасове або постійне перебування і ці послуги включають комплекс послуг інфраструктурних секторів гостинності. На нашу думку, продукт гостинності це комплексний, сукупний набір послуг, зв'язаних між собою логістичним ланцюгом, що об'єднує певний набір проміжних послуг різних інфраструктурних секторів (або в межах сектору) в результаті якого одержують продукт гостинності. Чим більш довгий логістичний ланцюг одержання кінцевого продукту гостинності, тим більше налічується послуг, які є кінцевими у одних логістичних ланцюгах, стають проміжними у інших. Так, наприклад, коли студент приїздить на навчання в інше місто, то гостинність цього міста буде визначатись комплексом послуг проміжного рівня, що формують кінцевий продукт гостинності.

Розглянемо послуги другого рівня від ступеню вражень, які отримують споживачі на прикладі сільського туризму.

Сільський туризм можна уявити за вражен-

нями:

- відпочинок;

- пізнавально-освітній туризм;

- туризм як театралізоване дійство, в якому турист бере безпосередню участь.

Перший ступінь вражень як просто від відпочинку - це чисте повітря, незаймана природа, неквапливий побут, тиша, натуральні продукти.

Однак даний вид відпочинку суворо персоніфікований для певного кола споживачів, для яких враження від нього будуть високі. Туристи готові будуть платити високу ціну за можливість побути на самоті, один на один $з$ природою. Вони купують можливість і час спілкування з природою в першу чергу, витрати на їжу, зупинка на ночівлю для них вторинні і можуть входити в ціну можливості знаходиться на природі.

Пізнавально-освітній сільський туризм - дає можливість вивчити місцевий побут (випікати хліб, вишивати тканини), можливість вивчати народні танці, художні промисли, фольклор краю, іноземні мови. Спеціальні навчальні курси припускають участь туристів у виробництві хліба, вина, олії охоплюють безліч стадій просування сировини до готового продукту. В даному випадку основу ціни за туристичні послуги становитиме плата за можливість навчитися, отримати розвиток, пізнати щось нове.

Театралізоване дійство в сільськогосподарському туризмі - перетворення послуги відпочинку, навчання, пізнання в театральну постановку, в якій $є$ сценарій і виконавці персонал, а також і сам споживач, залучений в дійство. Театралізація включає: наявність сценарію (головної теми), створення позитивних емоцій, відсутність негативних емоцій, пропозиція сувенірів як символів цінності спогадів, включення всіх п'яти органів почуттів. У сільській садибі розгортається чарівне дійство, що перетворює туристів зі спостерігачів на повноправних учасників.

В умовах сучасних змін в економіці, економічних пропозиціях, переходу від виробництва товарів й послуг до вражень та емоцій, які вони надають покупцям, ми переходимо до нової економіки - економіки вражень. Економіка нових та більш емоційних вражень в першу чергу пов'язана зі сферою гостинності, в той же час враження одержуються від проміжних послуг, що пов'язані із діяльністю інших секторів національного господарства. На нашу думку, економічне визначення гостинності полягає у тому що це набір послуг, які надаються, товарів що необхідні для їх надання та враження, що отримують споживачі від одержання цих послуг. Враження базуються на якості, ціні, організаційних і морально-етичних, культурних та екологічних умовах обслуговування. Гостинність визначається всією системою суспільних відносин у виробництві, розподілі, обміні, споживанні виробленої послуги або товару для іï надання.

Політика гостинності повинна охоплювати всі структурні елементи по горизонталі та вертикалі, які в цілому служать для її реалізації [5].

Враження охоплюють суспільні відношення в усіх напрямках. Для гостинності це можуть бути комплексні та одиничні, загальні та приватні враження. Загальні враження складаються 3 комплексу вражень та емоцій. Так, наприклад, враження відвідувача від ресторану складаються 3 екстер'єру, зручності під'їзду, інтер'єру, обслуговування, кухні, чистоти залу, це набір факторів, що впливають на враження. Якщо один 3 них не буде відповідати вимогам відвідувача, то загальне враження від ресторану буде низьким і не виникне бажання відвідати цей заклад ще ра3. 
Гостинність розглядається нами як економіка вражень, які отримують люди від відвідування різних місць відпочинку і роботи та одержання послуг у нематеріальній сфері. Це система надбудовних відносин гостинності, базовими елементами якої $є$ : враження по сферам основної та неосновної діяльності, послуг в наданні житла та іншому розміщенні та його обслуговуванні, відпочинку та розваг, освіти, охорони здоров'я, комунікацій та транспортування для:

- проживаючого населення;

- для приїжджого населення для одержання освіти, послуг лікування, оздоровлення та іншої мети проживання;

- біженців;

- емігрантів;

- туристів.

Поняття гостинність - складається з вражень та будується на соціальній і економічній еволюції потреб суспільства, що визначають напрям розвитку соціально-економічних систем в глобальному просторі. Гостинність - враження та емоцій $є$ складовою частиною якості життя.

«Гостинність - враження» має розглядатися як виникнення нових потреб суспільства у придбанні вражень, що забезпечуються товарами та послугами в процесі їх виробництва, обміну та споживання. Товари та послуги, що виробляються для системи «гостинність - враження» об'єднанні логістичними зв'язками і не можуть існувати окремо. Логістичний ланцюг у системі «гостинність - враження» це упорядкована множина суб'єктів логістичного процесу, що виробляють товари для надання послуг, доводять товар до суб'єктів надання послуг, які надають кінцеві послуги споживач. Схема логістичного ланцюга створення кінцевого продукту гостинності представлена на рис. 1, розроблена відповідно досліджень автора [6].

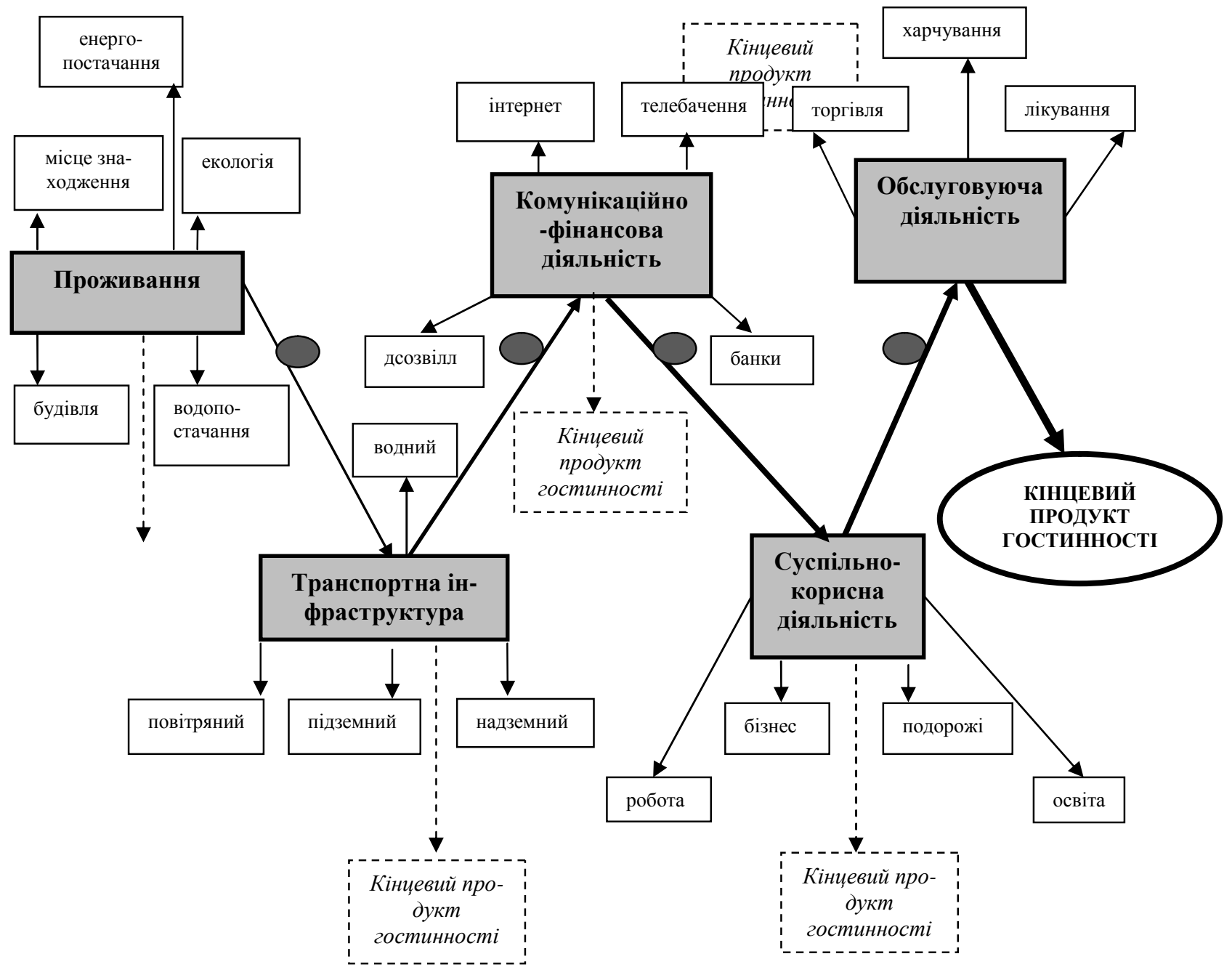

проміжні послуги

Рис. 1 Схема логістичного ланцюга створення кінцевого продукту гостинності [авторська розробка] 
Головні логістичні ланцюги в системі «гостинність - враження»: робота, освіта, дозвілля (кіно, театр, ресторан), відпочинок (всі види туризму), охорона здоров'я, транспорт, комунікації, адміністративні послуги, соціальне забезпечення, якість довкілля тощо.

Розглянемо, як приклад, логістичні зв'язки що формуються у сфері транспортної галузі. Невід'ємною частиною гостинності є природні умови і якість природних ресурсів, що використовуються в сфері гостинності, так само як і забезпечення екологічної безпеки умов відпочинку, лікування, оздоровлення приїжджих і місцевого населення, які залежать від діяльності всіх суб'єктів рекреаційного та інших напрямків господарювання, розташованих в даному регіоні. Це стосується, в тому числі, і транспортної

інфраструктури як складової «зеленої» логістики індустрії гостинності.

Активне використання «зеленої» логістики в гостинності обумовлено такими тенденціями і брендами, як підвищення інформованості споживачів за допомогою екологічного маркування товарів, необхідних для забезпечення життєдіяльності населення і туристів, стандартизація екологічної якості навколишнього природного середовища та природних ресурсів, що використовуються в рекреаційно-туристичній діяльності, а також збільшенням попиту на відповідних фахівців.

В даний час викиди забруднюючих речовин від пересувних джерел складають чималі обсяги i, тому, впровадження зеленої логістики в транспортній інфраструктурі індустрії гостинності відіграє особливо важливу роль. У цій сфері транспорт забезпечує доставку суб'єкта-гостя (проживаючого населення та туристів) до місця призначення, і його пересування в межах перебування. Також транспортна інфраструктура використовується для доставки продуктів і інших необхідних товарів, які забезпечують життєдіяльність, відпочинок і розваги суб'єктів сфери гостинності. У загазованих регіонах рекреаційні здатності екосистем різко знижуються, що негативно впливає на туристів і бажання постійного проживання на даній території. У зв'язку з цим актуальними стають питання нормування викидів забруднюючих речовин (3В) від пересувних джерел, плати за нормативні і наднормативні викиди 3В, організаційного механізму ïx справляння і розподілу між бюджетами, а також перерозподілу на природоохоронні та атмосфероохоронного заходи (озеленення територій, створення паркових зон та ін.). В «зеленої» логістиці особливу увагу слід звернути на річковий та морський транспорт, так як його функціонування нерозривно пов'язане 3 місцями рекреації та відпочинку, розваги та оздоровлення суб'єктів і діяльності об'єктів гостинності. При нанесенні шкоди водним об'єктам стягується плата, яка спрямовується до місцевих бюджетів, проте безпосередньо на компенсацію зниження якості природних об'єктів сфери гостинності кошти не спрямовуються, що призводить до зменшення потоку гостей і відповідних збитків санаторіїв, курортів, будинків відпочинку та інших.

В сучасних умовах необхідна розробка організаційно-економічного, фінансового і правового механізмів забезпечення взаємовідносин між транспортними підприємствами забруднювачами і суб'єктами гостинності. В основу такого механізму повинно бути покладено запобігання зниження якості навколишнього природного середовища від пересувних джерел забруднення; економічна та екологічна компенсація втрат об'єктів гостинності, а також запобігання соціальної і моральної незадоволеності гостей. Тільки коли забруднювачі почнуть втрачати прибуток через взаєморозрахунків зі сферою гостинності, і для них стане економічно недоцільним забруднення навколишнього середовища, тільки тоді вони будуть мотивовані до зниження обсягів забруднення. Специфіка підприємств інфраструктури гостинності полягає в тому, що вони спрямовані на збільшення i поліпшення якості споживчих послуг населенню i приїжджим і отриманні синергетичного ефекту від їх взаємодії, на основі «зеленої» логістики. Кожний окремий ланцюг гостинності в свою чергу складається $з$ власних ланцюгів, що забезпечують його функціонування та одержання враження. В якості логістичної системи можна розглядати кожний окремий ланцюг.

Висновки і перспективи подальших досліджень. В умовах зміни світогляду та переходу до нових моделей економічного розвитку с акцентом на соціальну та емоційну складову, від простого отримання товару або послуги - до враження та емоції (які отримує споживач), формується нова економіка економіка вражень. Така економіка безпосередньо пов'язана зі сферою гостинності, яка формує кінцеві та проміжні враження від продукту гостинності. На нашу думку, продукт гостинність визначається сукупністю проміжних та кінцевих послуг ії інфраструктурних секторів, що пов'язані логістичними ланцюгами як у середині секторів так і між ними. Економічна сутність гостинності полягає у тому, що це комплекс товарів та послуг, які необхідні для формування вражень споживачів.

\section{Література}

1. Про Програму діяльності Кабінету Міністрів України «Назустріч людям» : затв. Постановою Кабінету Міністрів України від 04.02.2005 р. № 2426-IV // Офіційний вісник України. - К., 2005. - № 6. - С. 348.

2. Про затвердження Програми діяльності Кабінету Міністрів України «Український прорив: для людей, а не політиків» : за станом на 16.01.2008 р. [Електронний ресурс] / Кабінет Міністрів України. - Програма 
від 16.01.2008 р. № 14. - Режим доступу: http://zakon.rada.gov.ua/cgi-bin/laws/main.cgi?nreg=n0001120-08

3. Програма економічних реформ на 2010 - 2014 роки «Заможне суспільство, конкурентоспроможна економіка, ефективна держава» : за станом на 02.09.2014p. [Електронний ресурс] / Президент України. - Указ від 02.06.2010 р. - Режим доступу : http://www.president.gov.ua/docs/Programa_reform_FINAL_1.pdf

4. Про затвердження переліку проектів із пріоритетних напрямів соціально-економічного та культурного розвитку (національні проекти) : за станом на 03.07.2015р. [Електронний ресурс] / Кабінет Міністрів України. - Постанова від 08.12.2010 року № 1256. - Режим доступу : http://zakon0.rada.gov.ua/laws/show/12562010-\%D0\%BF

5. Стратегія сталого розвитку «Україна - 2020» : за станом на 12.01.2015p. [Електронний ресурс] / Президент України. http://search.ligazakon.ua/l_doc2.nsf/link1/U005_15.html

6. Основы индустрии гостеприимства / [Д.И. Елканова, Д.А. Осипов, В.В. Романов., Е.В. Сорокина]. М.: Дашков и Ко, 2009. - 248c.

7. Мидлтон В. Менеджмент туризма / В. Мидлтон. - М.: Юнити, 2009. - 536 с.

8. Сагалакова Н.О. Характеристика туристичного продукту як специфічного об'єкту ціноутворення / Н.О. Сагалакова // Інвестиції: практика та досвід. - 2015. - №17. - С.27-33.

9. Вебстер Н. Толковый словарь [Електронний ресурс] / Словари онлайн. - Режим доступу http://slovar-vocab.com/english/merriam-webster-dictionary.html.

10. Дишкантюк О.В. Theoretical and methodological principles of development strategic planning of hospitality industry / О.В. Дишкантюк // Концептуальні засади економічного зростання в умовах глобалізації: [кол. монографія] / за ред. д.е.н., проф. В. Яценко. - Німеччина: Verlag SWG imex GmbH Nurnberg, 2016. - C. 443-454

11. Дишкантюк О.В. Формування інфраструктурного забезпечення сфери гостинності / О.В. Дишкантюк // Економіст. - 2016. - № 7. - С.25-28.

Стаття надійшла 14.11.2016

Стаття прийнята до друку 28.11.2016

Доступно в мережі Internet 30.12.2016

Дышкантюк О.В.

кандидат технических наук, доцент

кафедра отельно-ресторанного бизнеса

Одесская национальная академия пищевых технологий

ул. Канатная, 112, м. Одеса, Украина, 65039

E-mail: dyshkantyuk@ukr.net

\section{ЭКОНОМИКА ВПЕЧАТЛЕНИЙ - СОВРЕМЕННЫЙ ЭТАП РАЗВИТИЯ ОБЩЕСТВЕННОГО ПРОИЗВОДСТВА}

В статье обоснованы предпосылки развития экономики впечатлений как современного этапа общественного производства на основе изменения в предпочтениях потребителей - от простого получения услуг и товаров, которые в условиях конкуренции являются равнозначными, до получения впечатлений от их приобретения. Были определены фракторы, воздействующие на трансакции и трансакционные издержки поиска многовариантных услуг, основными из которых являются затраты времени, субъективность оценок, сложность осуществления оценки соотношения качества, цены, впечатлений и других потребительских характеристик товара или услуги. Предложено рассматривать гостеприимство как впечатления, получаемые людьми от промежуточных и конечних услуг.

Доказано, что к промежуточному уровню необходимо относить единичные услуги, не требующие комплекса взаимосвязанных услуг, находящихся в логистической цепи; услуги второго или конечного уровня включают комплекс услуг инфраструктурных секторов гостеприимства и фрормируют продукт гостеприимства. Определен продукт гостеприимства как комплексная совокупность услуг, связанных между собой логистической цепочкой, которая объединяет определенный набор промежуточных услуг различных инфраструктурных секторов (или в пределах самого сектора), в результате котрого потребители получают продукт гостеприимства. Обосновано, что чем длиннее логистическая цепь получения конечного продукта гостеприимства, тем больше насчитывается услуг, которые являются конечными в одних логистических цепах и становятся промежуточными для других.

Ключевые слова: экономика впечатлений, гостеприимство, конечные и промежуточные услуги, продукт гостеприимства, логистическую цепь, зеленая логистика. 


\author{
Dyshkantiuk 0. \\ Ph.D. in Technical Sciences, Associate Professor \\ Department of hotel and restaurant business \\ Odessa National Academy of Food Technologies \\ Kanatna str., 112 , Odessa, Ukraine, 65039 \\ E-mail: dyshkantyuk@ukr.net
}

\title{
ECONOMY OF IMPRESSIONS - CURRENT STAGE OF DEVELOPMENT OF SOCIAL PRODUCTION
}

In the article the preconditions of experience economy development as the current stage of social production is provided. It based on the advantages from simple consumer preferences for services and goods that in a competitive are equal, to getting impressions of their purchase. The factors, affecting the transaction and the transaction costs of multivariate search services are defined, the main of them are: time expenses, subjective assessments, the complexity of the valuation ratio of quality, price, experience and other consumer preferences of goods or services. Hospitality is considered as the impression that people obtained by the services of the first and second levels, which are divided into intermediate and final.

It is proved that the intermediate level necessary refer to individual services that do not require complex of related services that are in the logistics chain; services of second level or final services including complex infrastructure sector services of hospitality and form its product. Hospitality product is defined as a complex of aggregate services, connected among themselves by the logistics chain that combines a set of intermediate services of various infrastructure sectors (or within the sector), in which the hospitality product is obtained. Proved that the longer hospitality logistics chain obtain the final product, requires more services that are final in the one logistics chain and intermediate in others.

Keywords: economy experiences, hospitality, final and intermediate services, product hospitality chain logistics, green logistics.

\section{References}

1. Pro Prohramu diialnosti Kabinetu Ministriv Ukrainy "Nazustrich liudiam" : zatv. Postanovoiu Kabinetu Ministriv Ukrainy vid 04.02.2005 r. № 2426-IV . (2005). Ofitsiinyi visnyk Ukrainy, 6, 348.

2. Pro zatverdzhennia Prohramy diialnosti Kabinetu Ministriv Ukrainy "Ukrainskyi proryv: dlia liudei, a ne politykiv" : zatv. Postanovoiu Kabinetu Ministriv Ukrainy vid 16.01.2008 r. № 14 . (2008). Retrieved October, 2016, from Rezhym dostupu: http://zakon.rada.gov.ua/cgi-bin/laws/main.cgi?nreg=n0001120-08

3. Prohrama ekonomichnykh reform na 2010 - 2014 roky "Zamozhne suspilstvo, konkurentospromozhna ekonomika, efektyvna derzhava" . (2010, June 2). Retrieved October, 2016, from http://www.president.gov.ua/docs/Programa reform_FINAL_1.pdf

4. Pro zatverdzhennia pereliku proektiv iz priorytetnykh napriamiv sotsialno-ekonomichnoho ta kulturnoho rozvytku (natsionalni proekty) . (2010, December 8). Retrieved November, 2016, from http://document.ua/prozatverdzhennja-pereliku-proektiv-iz-prioritetnih-naprjam-doc43382.html

5. Stratehiia staloho rozvytku "Ukraina - 2020". (2015, January 12). Retrieved November, 2016, from http://search.ligazakon.ua/l_doc2.nsf/link1/U005 15.htm

6. Elkanova, D. Y., Osypov, D. A., Romanov, V. V., \& Sorokyna, E. V. (2009). Osnovы yndustryy hostepryymstva. M.: Dashkov y Ko.

7. Mydlton, V. (2009). Menedzhment turyzma. M.: Iunyty.

8. Sahalakova, N. O. (2015). Kharakterystyka turystychnoho produktu yak spetsyfichnoho ob'iektu tsinoutvorennia . Investytsii: praktyka ta dosvid, 17, 27-33.

9. Vebster, N. Tolkovbil slovar. Retrieved November, 2016, from http://slovar-vocab.com/english/merriamwebster-dictionary.html. - Zahl. z ekranu

10. Dyshkantiuk, O. V., \& Yatsenko, V. (2016). Theoretical and methodological principles of development strategic planning of hospitality industry . Kontseptualni zasady ekonomichnoho zrostannia v umovakh hlobalizatsii, 443-454.

11. Dyshkantiuk, O. V. (2016). Formuvannia infrastrukturnoho zabezpechennia sfery hostynnosti. Ekonomist, 7, 25-28. 